\title{
SURVEYING THE CHALLENGES AND OPPORTUNITIES OF AMERICA'S FOREIGN POLICY TOWARD CENTRAL
}

A S I A

\author{
ANDREAS BORGEAS IS THE \\ PROFESSOR OF INTERNATIONAL \\ LAW AT THE SAN JOAQUIN \\ COLLEGE OF LAW IN CLOVIS, \\ CALIFORNIA. HE CONDUCTED \\ RESEARCH FOR THIS ARTICLE IN \\ THE REPUBLIC OF KYRGYZSTAN, \\ THE REPUBLIC OF UZBEKISTAN \\ AND WHILE A POLICY SPECIALIST \\ FELLOW AT THE U,S, EMBASSY IN \\ the REPUBLIC OF KaZAKHSTAN. \\ PROFESSOR BORGEAS IS ALSO \\ A DOCTORAL CANDIDATE AT \\ THE DEPARTMENT OF POLITICAL \\ SCIENCE OF THE NATIONAL AND \\ KAPIDOSTRIAN UNIVERSITY OF \\ ATHENS,
}

America's record of engagement in Central Asia $^{i}$ has been extensive during its post-9/11 era of adventurism. Between its vast military infrastructure and its explosive expansion of new commercial and security networks, the US has invested enormous resources in Central Asia in the last fourteen years. Consequently the US has financed repressive governments, ignited religious resistance groups, and exacerbated tensions with neighboring powers Russia and China. Indeed the US recalibrated its traditional foreign policy toward this region in order to pursue a forward operating position in the theater of Central Asia in support of the mission in Afghanistan.

Yet with the continuing withdrawal from Afghanistan and its more recent commitment to an Asia-orientated foreign strategy, the US is on track to dramatically decrease its investment in the region. Inevitably, competing agendas will be aggressively maneuvering in the vacuum for greater regional influence. In light of these realities it remains vital for the US to restrain the mounting momentum

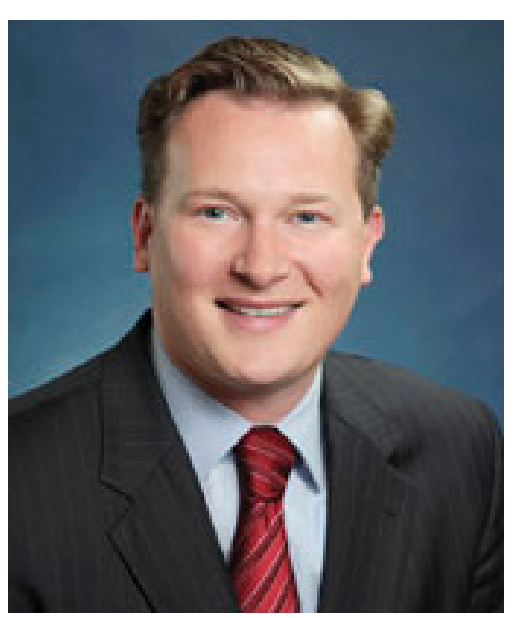

for disengagement and for policymakers to more concretely identify the US' continued security, political and economic commitments to Central Asia. Failure to do so would, at best, undermine the stabilizing achievements the US has earned to date, or, at worst, render its investments worthless and further destabilize a strategically important region of the world.

This article examines the US' engagements in Central Asia and surveys a select number of challenges and opportunities ahead for US policymakers amidst the managed withdrawal from the region. This article goes on to selectively examine the US' record of investments and particular interests that warrant monitoring in individual Central Asian states, regional and state specific challenges, and tools that can help promote more regional stability. This article also provides the following policy recommendations: that to promote greater stability in Central Asia, US policymakers should continue to emphasize economic development through regional and global market integration, support regional cooperation alongside evolving notions of state sovereignty, and encourage policies to address the political, social and religious grievances that give rise to Islamic extremism. 
Finally, this article recommends that for lasting stability the US should remain actively engaged in Central Asia by incorporating the republics as the western flank of America's pivot policy toward Asia. ${ }^{\text {ii }}$

\section{SURVEYING US INVESTMENT IN THE NORTHERN DISTRIBUTION NETWORK}

It was not until 2001 that significant US interests in Central Asia expanded beyond natural resources and the containment of nuclear materials left over by the former Soviet Union. By the end of 2001 the US was aggressively pursuing strategic alliances in Central Asia by offering significant financial incentives to secure military bases, air rights, and transit routes necessary to facilitate A fghan operations. These routes through Central Asia became known as the Northern Distribution Network (NDN), which included transit and other logistical operations in Kazakhstan, Kyrgyzstan, Tajikistan and Uzbekistan. One of the US' most significant tactical gains in the region was securing a lease to the Transit Center at Manas Air Base in Kyrgyzstan. Because it had to outmaneuver Russian opposition the lease came at a significant financial cost to the US, which included hefty lease payments, landing fees, infrastructure upgrades, and hundreds of millions of dollars per year in related purchases. Kyrgyzstan allowed the US a terminal lease at Manas from 2010 through 2014, but the agreement included a substantial rent increase from $\$ 17.4$ million per year to $\$ 60$ million per year. ${ }^{1}$

The US was also granted the use of the Karshi-Khanabad Air Base by the Uzbek government as a logistical base along the NDN that accommodated both air and land transport. US forces were similarly granted the use of the Dushanbe International Airport in Tajikistan for refueling purposes and the
Almaty International Airport in Kazakhstan for emergency landings in 2002. However, in 2005 the US lost its permission to use the base at Khanabad and was ordered to vacate in retaliation for US criticism over the Uzbek government's suppression of the Andijon demonstrations earlier that year. After the diplomatic rift in 2009 relations were partially repaired between the US and Uzbek governments after Uzbekistan, Kazakhstan and Tajikistan all agreed (with some caveats) to allow US forces to transit materials via both air and land into Afghanistan along the NDN. While Kazakhstan and Uzbekistan agreed weapons could be transported by air they only allowed non-lethal supplies to be transported by land. The Tajik government also agreed to allow the land transit of goods and supplies into Afghanistan, which is off the main route of the NDN and serves as an alternative route for a small percentage of supplies. Corresponding with the 2009 agreements, Kazakhstan saw the most dramatic percentage increase in US foreign aid, followed respectively by Kyrgyzstan, Uzbekistan, Turkmenistan and Tajikistan. ${ }^{2}$ Additionally, the US has paid several hundred millions of dollars per year in related goods and transit fees. ${ }^{3}$

\section{BY THE END OF 2001 THE US WAS} AGGRESSIVELY PURSUING STRATEGIC ALLIANCES IN CENTRAL ASIA BY OFFERING SIGNIFICANT FINANCIAL INCENTIVES TO SECURE MILITARY BASES, AIR RIGHTS, AND TRANSIT ROUTES NECESSARY TO

FACILITATE AFGHAN OPERATIONS. 
* 4 (see also endnote 5 for additional information on 2012-2015 US AID Foreign Assistance)

\begin{tabular}{|l|l|l|l|l|l|}
\hline (In millions) & $\mathbf{2 0 0 9}$ & $\mathbf{2 0 1 0}$ & $\begin{array}{c}\text { \% Change } \\
(\mathbf{2 0 0 9 - 2 0 1 0})\end{array}$ & $\mathbf{2 0 1 1}$ & $\begin{array}{c}\text { \% Change } \\
(\mathbf{2 0 1 0 - 2 0 1 1})\end{array}$ \\
\hline Kazakhstan & 91.98 & 316.8 & $244.4 \%$ & 89.98 & $-71.6 \%$ \\
\hline Kyrgyzstan & 51.9 & 114.0 & $119.7 \%$ & 59.75 & $-47.6 \%$ \\
\hline Tajikistan & 49.25 & 74.42 & $51.1 \%$ & 35.92 & $-51.7 \%$ \\
\hline Turkmenistan & 11.99 & 19.26 & $60.6 \%$ & 9.46 & $-50.9 \%$ \\
\hline Uzbekistan & 18.0 & 31.15 & $73.1 \%$ & 18.7 & $-40.0 \%$ \\
\hline
\end{tabular}

Capitalizing on the financial benefits of the NDN, Kazakhstan, Uzbekistan and Kyrgyzstan all agreed in 2012 to allow US and North Atlantic Treaty Organization (NATO) forces reverse transit of cargo and personnel out of Afghanistan in anticipation of the US withdrawal..$^{5}$ Throughout its involvement in Afghanistan the US has maintained direct military cooperation with Tajikistan; in contrast, Turkmenistan has only supported humanitarian efforts towards Afghanistan due to its close ties with Iran and the Taliban.

\section{ENERGY, AID AND OTHER}

\section{INTERESTS}

Beyond military and security investments, US interests in Central Asia have primarily been in the areas of energy and aid. While its influence has been in decline due to increasing Chinese and Russian investment, ${ }^{6}$ US business interests still maintain a significant stake in Central Asian energy. The overarching issue for US energy activities has been how to get energy commodities out of landlocked Central Asia. The politics of pipelines seem as tangled as the routes themselves with each route presenting its own obstacles. US policy historically has been to cultivate opportunities in ways that bypass and isolate both Russia and Iran. The most significant US developments occurred in the 1990s with the unveiling of the Eurasian Transportation Corridor, which reflected a policy decision to encourage multiple pipelines out of Azerbaijan, Turkmenistan and Kazakhstan into Turkey without crossing Iran and giving Russia undue sway over the routes.

Power sharing agreements have since declined in Central Asia in favor of joint ventures, which enable the host country or host business to establish ownership interests and simultaneously develop expertise in the enterprise. One of the more prominent US company joint ventures in Central Asia includes the Chevron-led Tengizchevroil Consortium, in which Kazakhstan's state oil and gas company, KazMunayGas, has a twenty percent interest. Tengizchevroil output is exported through the Caspian Pipeline Consortium and the Trans-Caspian Transportation network. Full development of the Tengizchevroil, Karachaganak and Kashagan fields is expected to double existing production by the year 2019 . While Turkmenistan has the second largest gas reserves in the world, foreign direct investment (FDI) has been minimal due to strict government control, corruption and underwhelming economic reforms. In addition, Uzbek reserves have also largely been closed to FDI from western sources.

American trade with the Central Asian states has been greatest with Kazakhstan. In 2011 the US exported approximately $\$ 826$ million 


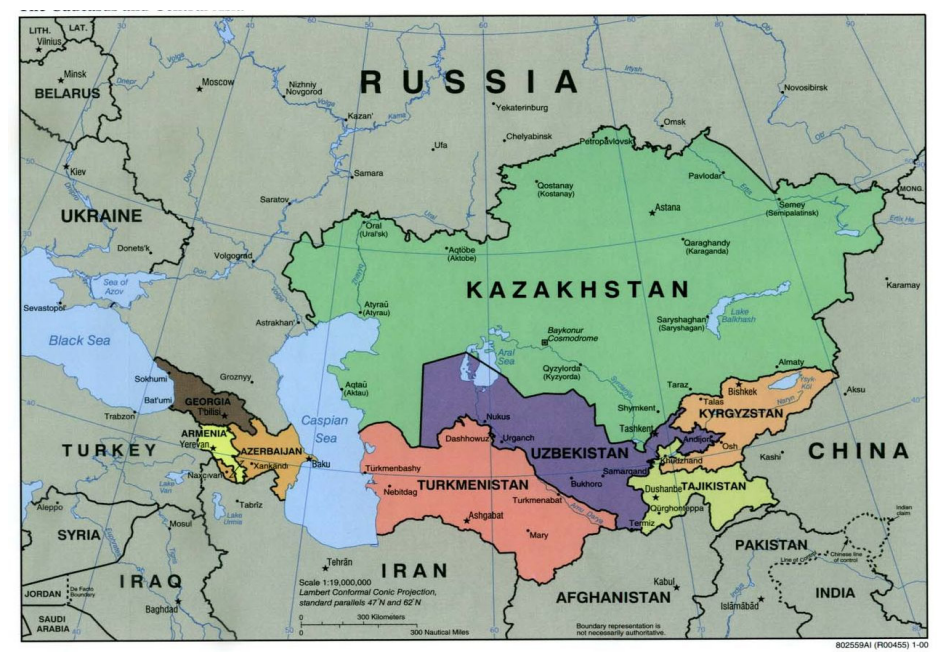

in goods, mostly machinery and transportation equipment, and imported approximately $\$ 1.7$ billion, mainly in oil and minerals. ${ }^{7}$ US companies with notable trade investments in Kazakhstan include Boeing, FedEx, and a joint venture between GE and Kazakhstan. US trade with the rest of the four Central Asian states has been minimal in comparison.

Over the past decade US aid to Central Asia has declined from approximately $\$ 328$ million in 2002 to approximately $\$ 96$ million in $2013 .{ }^{8}$ Kazakhstan has been the largest recipient of US aid among the five republics from 1992 through 2010 , followed respectively by Kyrgyzstan, Tajikistan, Uzbekistan and Turkmenistan. ${ }^{9}$ A past focus of US aid to Kazakhstan had been the Comprehensive Threat Reduction program (CTR), which contained and eliminated post-Soviet nuclear materials. In contrast, US aid for 2014 emphasized peace and security, including anti-terrorism training and border controls, economic development and democratization. ${ }^{10}$ Previous US aid packages to Kyrgyzstan included humanitarian assistance, but future aid will be focused on supporting democracy and encouraging economic and governmental agency reforms. ${ }^{11}$ Tajikistan also received US aid for humanitarian assistance in the past, but future aid now focuses on combating Tajikistan's serious drug trafficking challenges as the country contains popular transit routes between Afghanistan, Russia and China. ${ }^{12}$

Uzbekistan is the largest Central Asian state by population and has the most advanced military of the five countries; it devotes ten percent of its GDP to defense. ${ }^{13}$ Prior US aid to Uzbekistan focused on the CTR program, humanitarian assistance and democratization. In recent years major human rights violations by the Uzbek government have triggered a withholding of US aid. However, the State Department has biannually waived the withholding determinations on national security grounds. ${ }^{14}$ In light of regional security concerns, the US' 2014 aid package to Uzbekistan was oriented toward security and anti-terrorism. ${ }^{15}$ Turkmenistan received the least amount of US aid in Central Asia and current appropriations focus on peace and security, government reforms, economic growth and combating drug and human trafficking. ${ }^{16}$

\section{SURVEYING THE CENTRAL ASIAN STATES}

Regional stability is the primary US objective in Central Asia. However, stability can only be achieved with economic reforms in these former Soviet satellites, including greater economic integration with neighboring countries and world markets. Economic integration also 


\title{
IN ADDITION TO SECURITY \\ COUNTERMEASURES, STABILITY \\ WILL ALSO REQUIRE POLITICAL \\ AND SOCIAL REFORMS.
}

\author{
PICTURED IS KAZAKHSTAN'S \\ PRESIDENT NURSULTAN NAZARBAYEV
}

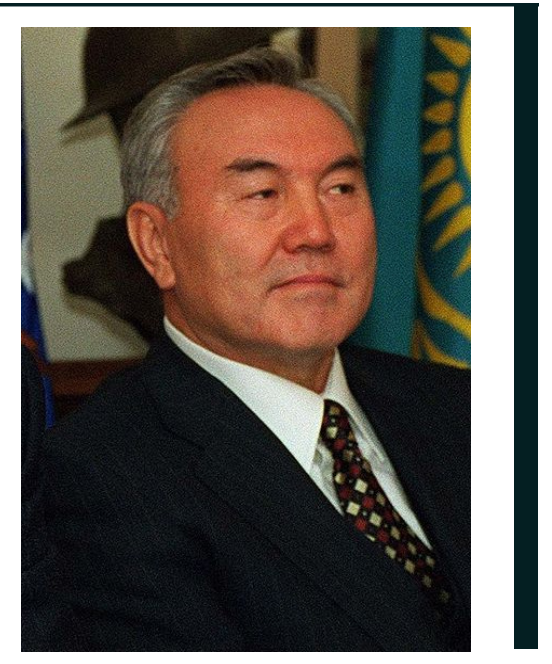

requires states to implement reforms that discourage corruption in both the public and private sectors, and build business infrastructure that encourages legitimate enterprise with foreign direct investment. In addition to security countermeasures, stability will also require political and social reforms to provide dissenting and minority groups with religious, social and political freedoms in order to mitigate extremism. Finally, all five countries face security threats from forces within and outside their borders that have resulted in border disputes, interethnic animosity and Islamic extremism.

\section{Kazakhstan}

The president of Kazakhstan is known to exercise near comprehensive political power, with democratic elections and voting procedures questioned by an assortment of international organizations. Kazakhstan has scored poorly with human rights groups due to its significant restrictions on freedoms of speech, assembly and religion, and for the recent use of deadly force in response to an energy workers strike in Zhanaozen in 2011. ${ }^{17}$ Other issues such as human trafficking and the use of child labor in agriculture have also been problematic. While the Kazak government has made inroads in these areas it has still not addressed government participation in these activities. ${ }^{18}$
Economic development has been stifled by corruption, banking system irregularities, modernization failures, inadequate business and trade laws, overly restrictive regulations, and a deficiency in social spending in areas such as health and education, especially in rural areas. Further evidence of government corruption surfaced in 2011 when the Karachaganak Petroleum Operating (KPO), an oil and gas consortium, was forced to give ten percent of its shares to the Kazakh government in exchange for lifting heavy fines and duties. ${ }^{19}$

\section{Kyrgyzstan}

The 2011 presidential election saw Kyrgyzstan's first peaceful transfer of power. While the US indicated that the election was a step in the right direction, the Organization for Security and Cooperation in Europe (OSCE) still reported the results as questionable. ${ }^{20}$ Government corruption remains epidemic; there is no independent judiciary and there are serious shortcomings in legal due process. Significant restrictions remain on freedom of religion and there are continued instances of arbitrary arrests, torture, and extortion against ethnic minorities, especially amongst Uzbeks in southern Kyrgyzstan. The issues of human trafficking and child labor are national concerns. While the government has strengthened the laws on 


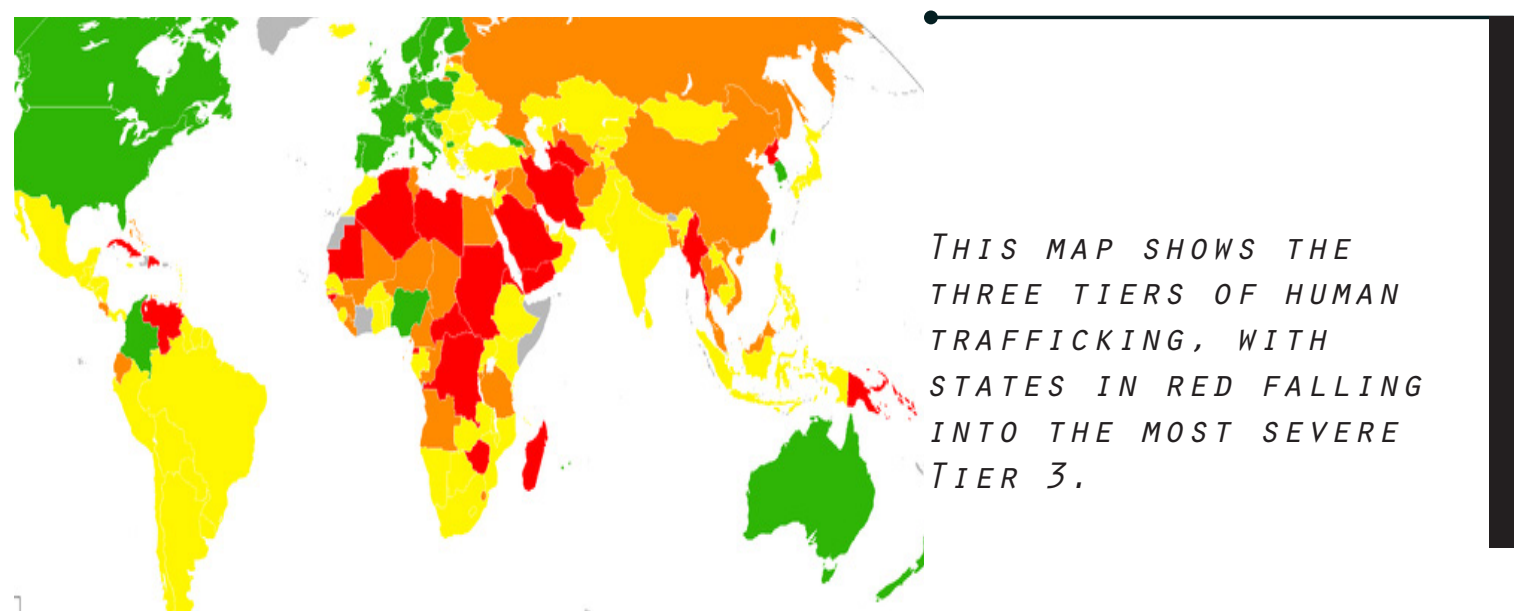

human trafficking no one has been prosecuted, and there is substantial suspected involvement by government officials in these activities. ${ }^{21}$

Economic development in Kyrgyzstan has been stifled due to public unrest over foreign backed projects, wide spread power outages and high prices for energy and gas. Foreign investment has declined and organized crime is again on the rise. Gold production, agriculture, and foreign remittances from Kyrgyz laborers in Russia are suspected of comprising a significant portion of the country's GDP. ${ }^{22}$

\section{Tajikistan}

Political freedoms in Tajikistan remain problematic. The OSCE reported Tajik elections offer no genuine choices for candidates and report seriously improbable voter turnout figures. ${ }^{23}$ It is a felony to criticize the Tajik president and political opponents are prosecuted, including former minister Zayd Saidov who was arrested one month after establishing the New Tajikistan opposition party. ${ }^{24}$ Without an independent judiciary, Tajik citizens have few if any due process rights. Arbitrary arrests, torture, and abuse of detainees by the police have been widely reported by third parties. ${ }^{25}$ In addition, freedom of press and religion are highly restricted. For example, in 2009 the Tajik government banned prayer in unregistered cities; restrictions were further tightened in 2011 when the Tajik government forbade children from participating in religious services and banned preaching without a permit. ${ }^{26}$ In 2012 the government installed cameras in mosques and students are now required to obtain government permission to study abroad or have ties with foreign religious groups. ${ }^{27}$ As a result of these religious restrictions, international observers are becoming increasingly concerned that Islamic extremism is appealing as the language of opposition.

Most Tajik citizens live in poverty. Human trafficking and forced labor during the cotton harvest remain issues. The country's economy relies heavily on drug trafficking, foreign loans, and remittances from migrant workers. Tajikistan is a main route for drug trafficking from Afghanistan where drug proceeds are linked to high-level government corruption. The Economist even reported that drug money is likely propping up the Tajik economy. ${ }^{28}$ State ownership of land and major enterprises combined with a weak banking system serve to discourage private sector development. Other problems include a lack of spending on social programs, aging infrastructure, and a shortage of teachers, doctors and other core service providers. 
In 2011 Uzbekistan was listed among the nine worst human rights abusers in the world. ${ }^{29}$ Democratic elections are illusory because opposition parties are prohibited from naming candidates. There are virtually no freedoms of speech, press, religion or assembly. Opposition members, journalists, and those who worship outside of state guidelines are subject to state prosecution. The media is state owned and there is massive censorship of television, the internet, cell phones and social media.

In 2005 Uzbek troops reportedly killed hundreds of demonstrators protesting the prosecution of prominent businessmen accused of terrorism in the city of Andijon. The Uzbek government rejected international attempts to inquire into the circumstances of the jail break, the attack or the arrests of the individuals allegedly responsible. The Uzbek government even evicted the US from its military base in Khanabad following US criticism, which prompted the European Union to ban visas for those Uzbek officials perceived as responsible for the Andijon suppression. ${ }^{30}$

In 2006 Uzbekistan was classified as a Country of Particular Concern (CPC) by the US for severe religious and human rights violations, and, in 2009 the US Commission on International Religious Freedom (USCIRF) ranked Uzbekistan as among the worst countries for religious freedom. ${ }^{31}$ Like Tajikistan, Uzbekistan is also a source of human trafficking for the sex trade and forced child labor remains a national problem.

Economically, the Uzbek government controls all export industries, including cotton, gold, and natural gas. Government seizure of foreign assets since 2010, strict border controls, and corruption have all led to a steep decline in foreign investment. ${ }^{32}$

\section{Turkmenistan}

Similar to Uzbekistan, Turkmenistan is ranked by Freedom House as one of the worst countries for human rights abuses. ${ }^{33}$ Politically, Turkmenistan remains mostly closed to Western influences. There are no democratic elections and only government approved candidates are eligible to run. The president exercises near comprehensive power and the country's new constitution allows presidential rule by decree. Freedom of the press, assembly and religion are severely restricted, and torture or abuse by authorities is so widespread the US State Department estimates one in every two detained citizens has been subject to some form of government abuse. ${ }^{34}$

Turkmenistan remains both a source and a destination for human trafficking, and the government has demonstrated little advancement in victim protection. Nearly one-third of the population lives in abject poverty and state ownership of industry, corruption, and inadequate market reforms have further dissuaded foreign investment. ${ }^{35}$ Even though Turkmenistan has declared drug addiction a national catastrophe, the government has not developed an adequate response to these concerns and focuses its investments toward the military rather than social infrastructure.

\section{SURVEYING CENTRAL ASIA'S}

\section{REGIONAL CHALLENGES}

Beyond the internal issues facing each republic, a number of regional challenges exist that compromise stability efforts in Central Asia. Many of these regional challenges include border disputes, natural resource conflicts, ethnic minority mistreatment, drug trafficking and terrorism. Uzbekistan, for example, shares borders with four neighbors and is often at the center of regional disputes, by either its own actions or those of organizations such as the Islamic Movement of Uzbekistan (IMU), a terrorist organization which aims to topple the Uzbek government and is known to operate within the neighboring republics.

The worst problem of ethnic violence in the region has been between Kyrgyz and ethnic 


\section{REGIONAL TENSIONS ARE FURTHER EX-}

ACERBATED BY THE “WATER WARS" BE-

TWEEN UZBEKISTAN AND KYRGYZSTAN,

UZBEKISTAN AND TAJIKISTAN AND - TO

A LESSER EXTENT - WITH TURKMENI-

$S T A N$.

Uzbeks in southern Kyrgyzstan near the Uzbek border. ${ }^{36}$ In June 2010 violent clashes reportedly resulted in 470 deaths with nearly 2,000 injured. ${ }^{37}$ Most of these casualties were considered ethnic Uzbeks. While Uzbekistan did not become involved in the fighting it did host over 100,000 Uzbek refugees on a temporary basis. As a result of this violence, the IMU vowed retaliation against the Kyrgyz government and has successfully recruited ethnic Uzbeks from southern Kyrgyzstan to join their movement. Both countries blame the other for harboring terrorists. Since 2010 gunfire and violence at the Kyrgyz-Uzbek border have resulted in tighter border crossings and a movement by the Uzbek government to seal and mine large portions of the border regions. ${ }^{38}$

Tajikistan and Kazakhstan have also experienced reported terrorist attacks in their respective countries from perpetrators with links to the IMU and other Islamic extremist groups. In 2003 Kazakhstan established the Anti-Terrorist Center as part of its National Security Committee and claims to have convicted over 300 people of terrorism since 2005. ${ }^{39}$ The 2010 terrorist attacks in Tajikistan, including a suicide car bombing and attack on a military convoy, have also been linked to the IMU. ${ }^{40}$ Uzbekistan itself has been accused of bombing the Tajik Supreme Court building in an effort to overthrow the Tajik government. ${ }^{41}$

Tajikistan also faces substantial threats from terrorism and drug trafficking activities arising out of Afghanistan, which have resulted in instability in the shared mountainous Badakhshan region. This region is a major transit corridor for drugs and other illicit goods smuggled into Tajikistan as well as weapons and financing being sent into Afghanistan. Making matters worse the Tajik government lacks the resources to properly secure the border, and border agents themselves have been reportedly participating in the trafficking enterprises. ${ }^{42}$ The Tajik government is also concerned about ethnic violence towards several million Tajiks in Afghanistan and the nearly one million Tajiks living in Uzbekistan.

Regional tensions are further exacerbated by the "water wars" between Uzbekistan and Kyrgyzstan, Uzbekistan and Tajikistan and - to a lesser extent - with Turkmenistan. In an effort to minimize its energy shortages, Kyrgyzstan plans to build a hydroelectric power plant on the Naryn River despite fierce opposition by Uzbekistan, which claims that such a project will restrict its own water supply. Similarly, Tajikistan would like to build a dam for its own power plant on the Vakhsh River but it too faces Uzbek opposition on grounds it will alter the environment and harm 
TURKMENISTAN HAS HAD THE LEAST AMOUNT OF

STRIFE WITH UZBEKISTAN, HOWEVER, IT TOO

HAS HAD TENSION WITH UZBEKISTAN REGARDING

WATER SHARING AND ACCUSATIONS OF REGIONAL

INTERFERENCE, ACCUSING UZBEKISTAN OF

ATTEMPTING TO ORCHESTRATE A POLITICAL COUP IN 2002 .

Uzbekistan's agricultural industries. In political brinksmanship, the Uzbek government restricted railway and road access to Tajikistan, boosted rail tariffs and cutoff gas supplies. ${ }^{43}$ The international community has proposed a water-for-gas trade between the countries but so far this idea has not been successful.

Turkmenistan has had the least amount of strife with Uzbekistan. However, it too has had tension with Uzbekistan regarding water sharing and accusations of regional interference, accusing Uzbekistan of attempting to orchestrate a political coup in 2002. Another regional challenge is the border dispute in the Soviet apportioned Fergana Valley, with Uzbekistan, Kyrgyzstan, and Tajikistan each vying for geographic control and regional influence in this Islamic heartland.

\section{TOOLS HELPING ACHIEVE STABILITY IN CENTRAL ASIA}

Each Central Asian republic has aspirations extending beyond the US withdrawal, and they invariably include lucrative relations with Russia and China. Both Russia and China have established military alliances to secure against Islamic extremism and post U.S. withdrawal instability, oil and gas pipelines, trade links for commercial goods, and strategic partnerships to extend their respective influence. China also has acute security interests in the Xinjiang region near the Kazakh and Kyrgyz borders where ethnic Uighurs are considered a substantial security risk. While population numbers remain disputed, it is estimated over 350,000 Uighurs live in Kazakhstan and Kyrgyzstan. ${ }^{44}$ Security disputes and accusations of mistreatment have at times caused tense relations between these neighboring nations. ${ }^{45}$
The Central Asian countries, with the exception of Turkmenistan, belong to both the Shanghai Cooperation Organization (SCO) and the Collective Security Treaty Organization (CSTO). The SCO includes China and Russia and focuses on security and combating terrorism. The CSTO, however, is anchored by Russia only and is intended to provide military support to CSTO members in prevention of outside aggression. The CSTO requires members to obtain CSTO permission before it can host a foreign military bases. Perceiving the treaty terms as excessively interfering with its sovereignty, Uzbekistan suspended its membership from the CSTO in 2012.

The Central Asian countries have not focused their interests exclusively on Russia and China. All five states are members of the Organization for Security and Cooperation in Europe (OSCE), which has fifty-seven member states from Europe, Central Asia, and North America. The OSCE's focus is on security, democracy, human rights, economic development and integration, and environmentalism. Recent OSCE agendas have included promoting stability in Afghanistan and encouraging economic integration between Afghanistan and Central Asia. ${ }^{46}$ Additionally, all five countries are members of NATO's Partnership for Peace and participate in Annual Bilateral Consultations with the US. These groups provide a forum for high level discussions on political and economic matters. On the economic side, Kyrgyzstan joined the World Trade Organization (WTO) in 1998, and Kazakhstan is expected to join in 2015 followed sometime thereafter by Tajikistan. ${ }^{47}$ While still in its formative stage, Russia and Kazakhstan are working to formally 


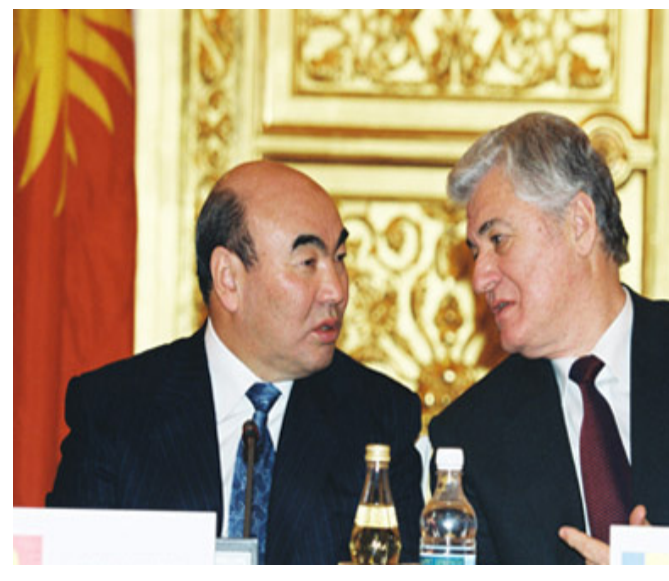

KYRGYZSTAN JOINED THE WORLD

TRADE ORGANIZATION DURING ASKAR

AKAYEV'S (PICTURED ON LEFT)

TIME AS PRESIDENT. establish the Eurasian Economic Union by 2015. ${ }^{48}$ This economic trade zone will likely seek to include the other nations of Central Asia.

Each nation has also made known its own policy goals for beyond 2015. As identified in the Strategy Kazakhstan 2050, Kazakhstan's priorities are upgrading and diversifying its energy infrastructure, promoting regional security, attracting foreign direct investment and strengthening the Customs Union to establish the Eurasian Economic Union. ${ }^{49}$ In addition, Kazakhstan will maintain its existing multi-vectored approach toward economic, security and political relations with Russia, China and the United States.

Kyrgyzstan aims to fight internal corruption and attract FDI to repair and upgrade its electrical system and agricultural infrastructure. It also supports a new railway proposed by China through Kyrgyzstan to Uzbekistan and another north-south railway. Kyrgyzstan currently leads Central Asia in the privatization of business and industry and would also like to continue to encourage foreign capital and investment. ${ }^{50}$

Both Kyrgyzstan and Tajikistan are seeking foreign investment to expand their hydroelectric stations that would accommodate sales in Afghanistan and Pakistan. Additionally, Tajikistan has agreed to cooperate with Afghanistan and Iran to build rail, electric, and water pipeline links for greater regional opportunities. Other major goals for Tajikistan include battling drug trafficking, organized crime, and terrorism. This includes encouraging regional cooperation and strengthening security in Central Asia. Additionally Tajikistan claims to have put forth a new effort to target government officials and authorities involved in drug trafficking. ${ }^{51}$

One of Uzbekistan's political objectives is strengthening its regional influence amongst the republics, maneuvering against heavyweight Kazakhstan, and limiting interference in Central Asia from outside influences, especially Russia. This includes expanding its own hydroelectric facilities to prevent Tajikistan and Kyrgyzstan from expanding their facilities and weakening Uzbekistan's position in the region. ${ }^{52}$

While Turkmenistan has significant cultural and economic ties with Iran, one of its stated goals in 2011 was to diversify gas routes via a trans-Caspian pipeline in hopes of accessing European markets. ${ }^{53}$ Additionally, it has agreed to construct the TAPI pipeline pending financing that will connect Turkmenistan to Afghanistan, Pakistan and India.

\section{RECOMMENDATIONS FOR US POLICY}

In order to establish lasting stability in the region 


\section{the US SHOULD REMAin ENGAgED IN CENTRAL ASIA BY CONTINUING TO PROMOTE ECONOMIC DEVELOPMENT THROUGH REGIONAL AND \\ GLOBAL INTEGRATION, IMPROVING REGIONAL COOPERATION ALONGSIDE EVOLVING NOTIONS OF SOVEREIGNTY, AND ENCOURAGING POLICIES AND REFORMS TO UNDERMINE THE APPEAL OF ISLAMIC EXTREMISM.}

the US should remain engaged in Central Asia by continuing to promote economic development through regional and global integration, improving regional cooperation alongside evolving notions of sovereignty, and encouraging policies and reforms to undermine the appeal of Islamic extremism. In this context, the following recommendations are made to US policymakers:

\section{Promoting Economic Development}

Economic development is essential to improving stability in Central Asia and the means by which the "New Silk Road" strategy can be accomplished. The New Silk Road is a generic title for an organically unfolding strategy that is intending to further open the markets of Central Asia to the larger markets of South Asia. Building upon ancient precedent, the Silk Road strategy is a natural exchange system for Central Asia, and China has already established itself as a powerful trading partner with most of the Central Asian states. Furthermore, promoting the New Silk Road strategy will further encourage Chinese foreign investment in Central Asia that can be directed towards strengthening the inadequate and aging infrastructure in each state.

In order for this strategy to be successful for all of Central Asia, as opposed to primarily benefitting China, US policy should remain oriented toward creating more conducive environments for FDI. This would include decreasing government corruption and organized crime and reforming business and banking laws that promote private industry. Kazakhstan, Uzbekistan and Turkmenistan all have significant oil and gas reserves, but inadequate infrastructure, inefficiencies, corruption, and general instability have inhibited the FDI necessary for their natural resource industries to reach their potential and promote diversification. If they can achieve the reforms necessary to attract FDI to better develop their respective resource industries, markets in Afghanistan, China, Russia, India, Pakistan, and even Europe will serve to further integrate Central Asia into global markets.

\section{Improving Regional Cooperation Alongside Evolving Notions of Sovereignty}

US policy should remain oriented toward promoting economic development through regional cooperation. One of the largest causes of tension is the "water war" between Uzbekistan and both Kyrgyzstan and Tajikistan over hydroelectric power plants in the upstream countries. While the global community has encouraged a "water for power" trade, which has so far been rejected by the parties, the US should more strongly encourage the countries to open discussions for a sustainable regional solution. Giving them the opportunity to resolve their regional differences on a global stage may allow them the prestige and respect they desire, and the opportunity to emerge as regional leaders 


\section{WhILE THE GLOBAL COMMUNITY HAS ENCOURAGED \\ A “WATER FOR POWER" TRADE, WHICH HAS \\ SO FAR BEEN REJECTED BY THE PARTIES, \\ THE US SHOULD MORE STRONGLY ENCOURAGE \\ THE COUNTRIES TO OPEN DISCUSSIONS FOR A SUSTAINABLE REGIONAL SOLUTION.}

apart from the ad hoc jockeying that currently exists with Russia and China. While the US may not have the political gravitas to insert itself directly into such discussions, it remains in a position to help facilitate discussions before any number of international forums. Success in this area may give these countries the credibility and confidence to undertake bolder reforms within Central Asia, including establishing the ever elusive Central Asian political block.

While the US should continue to promote economic cooperation in Central Asia, it should also simultaneously support respective notions of state and regional sovereignty. While these notions may appear initially to be in conflict they exist regularly in the dynamic tension of statecraft; encouraging policymakers to evaluate under which circumstances regional cooperation or political independence is more beneficial. Promoting sovereignty will help increase the maneuverability of each country to develop alliances with Russia, China, the West, as well as among themselves in order to advance their respective interests, thereby creating a balance of power that will favor no one country and maintain buffers with neighboring powers Russia and China. A multi-polar dynamic will serve to further increase stability in the region that would not be available from any one power alone. ${ }^{54}$

\section{Undermining Religious Extremism}

US policy should continue to encourage reforms and adjustments that undermine the allure of Islamic extremism by focusing on the political, economic, educational and religious challenges giving it rise as an opposition force. In particular, US policy should support the following: ${ }^{\text {ii }}$

1) Encourage the Republics to Legalize Political Parties Associated with the Islamic Faith. Circumstances indicate that political activism premised on the Islamic faith could achieve traction in Central Asia. While the republics are essentially secular, they need not deny registration to political parties associated with the Islamic faith. Already outlawed parties, such as Hizb ut-Tahrir, ${ }^{55}$ are cultivating support in Central Asia. The continuation of these ultrasecular policies risk disenfranchising moderate forces from the political process. These current practices force political expression underground and increase the appeal of more extreme and often foreign-based strains of Islamic thought. If these Central Asian states were to grant limited recognition to faith-associated parties, which disavow revolutionary or Sharia ambitions, they could help marginalize the appeal of Hizb utTahrir and similar political groups in favor of more moderate political activism, thus drawing more into an approved political outlet. ${ }^{56}$

2) Encourage the Republics to Sponsor the Study of Islam by Financially Supporting Officially Sanctioned Islamic Educational Institutions. Central Asia is known for having a shortage of formal faith-based educational and community institutions. This has encouraged a significant amount of underground, study abroad and foreign-financed activities, the consequences of which remain questionable but predictably dangerous. ${ }^{57}$ As a practical matter, when faith-based institutions are highly dependent on foreign donors, from such places as Saudi Arabia and Pakistan, foreign elements are brought into the equation that may bear on the type of instruction and curricula provided. In effort to maintain the moderate practice of Islam in Central Asia, to which its common religious traditions are already oriented, it would seem prudent for the CentralAsia republics to moderate their policies and invite a more transparent religious infrastructure and endowment process to be created for which these republics could temporarily provide financial support. 


\section{3) Encourage the Republics to Implement More} Preventive Tactics in Effort to Combat Terrorism. Like those of Russia and China, Central Asian security practices are more suppressive than they are preventative, in contrast to those promoted by the US and NATO. Suppression policies are oriented toward eliminating the opportunity for terrorists to carry out attacks, while prevention is oriented toward mitigating the social, religious or economic factors that give rise to Islam as an opposition force. Strict suppressive countermeasures such as religious registration requirements and obtrusive monitoring compound the sentiments of extremism by exacerbating the underlying grievances. It is unlikely that terrorism will ever be eradicated by solely suppressive or preventative policies, but gains would likely be enhanced if a comprehensive approach were used that incorporates both types of policies. Repressive state tactics that target religious groups and freedom of expression often alienate moderate elements, which are the very segments that can effectively marginalize extremism. As such, Central Asian security policies should hone in on the underlying causes of radicalism, which are known to be unemployment, limited professional and educational opportunities, religious and social repression and an exclusionary political process. ${ }^{\text {iv }}$

\section{CONCLUSION}

Last year marked the beginning of a systematic withdrawal of US forces from Afghanistan and the declared advent of America's recalibrated Asian orientation. As the US decreases its investment in the region, it remains vital for the US to restrain the mounting momentum for disengagement and for policymakers to more concretely identify America's continued commitment to Central Asia. The US' foreign policy agenda may not always be as concerned with the region in the decades to come, but there is a unique opportunity occurring for the US to be instrumental in building a more stable region as the aging strongmen of Central Asia transition out of power. This forthcoming leadership changeover is indeed a rare opportunity. If the US disengages too abruptly it risks forfeiting the opportunity today to help forge the Central Asia of tomorrow. Therefore, in order to assure its participation in and relevance to the region, the US should incorporate the republics as the western flank of America's pivot policy toward Asia. In this way America's reputed containment policy toward China engages and affects not just Eastern Asia but Western Asia as well.

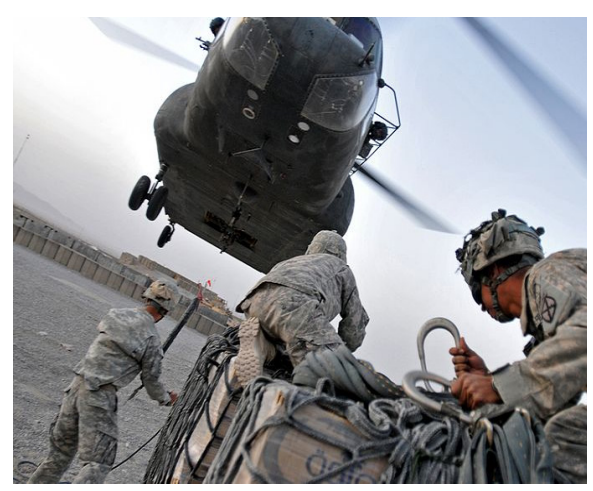

